\title{
ORAL ADMINISTRATION OF N-ACETYLCYSTEINE IMPROVES BIOCHEMICAL PARAMETERS IN DIABETIC RATS
}

Jamile Fabbrin Gonçalves', Cinthia Melazzo Mazzanti ${ }^{2}$, Alexssandro

Geferson Becker², Rosilene Rodriguez Kaizer ${ }^{2}$, Vanessa Battisti ${ }^{2}$, Maísa de Carvalho Corrêa ${ }^{2}$, Paula Acosta Maldonado², Roberta Schmatz ${ }^{2}$, Gustavo Roberto Thomé ${ }^{2}$, Vera Maria Morsch ${ }^{2}$, Maria Rosa Chitolina Schetinger ${ }^{2}$

'Departamento de Bioquímica - ICBS/UFRGS; Porto Alegre, RS

${ }^{2}$ Departamento de Química - CCNE/UFSM; Santa Maria, RS

e-mail: jamilefabbrin@yahoo.com.br

\section{Resumo}

O diabetes mellitus é uma condição crônica complexa que é uma das principais enfermidades ao redor do mundo. Muitas evidências suportam que a hiperglicemia crônica conduz a uma série de eventos bioquímicos resultando na produção de estresse oxidativo e danos neurológicos. Portanto, as terapias adjuvantes que utilizem compostos antioxidantes contra esta patologia têm sido sugeridas. O composto N-acetilcisteína (NAC) tem importantes propriedades antioxidantes e neuromodulatórias. Portanto, considerando que o estresse oxidativo e as disfunções colinérgicas têm sido associadas com a patogênese de diferentes complicações diabéticas, o objetivo deste estudo foi investigar o efeito da NAC sobre parâmetros de estresse oxidativo e a atividade das enzimas acetilcolinesterase (AChE) e aminolevulinato desidratase (ALA-D) em ratos normoglicêmicos e diabéticos. Os animais receberam 50 ou $200 \mathrm{mg} / \mathrm{kg}$ NAC por gavagem diariamente, durante 45 dias. Os resultados mostraram uma falta de uniformidade na atividade da AChE entre as quatro estruturas cerebrais. Embora nenhuma 
dose de NAC tenha produzido atividade hipoglicemiante significativa, a dose de $50 \mathrm{mg} / \mathrm{kg}$ de NAC reverteu parcialmente a perda de peso corporal dos diabéticos e foi efetiva em restaurar a atividade da ALA-D e o conteúdo de tióis não-protéicos no fígado, além de diminuir a carbonilação protéica sérica. A dose de $200 \mathrm{mg} / \mathrm{kg}$ de NAC apresentou alguns efeitos per se negativos em ambos os sistemas antioxidante e colinérgico. Portanto, concluímos que a administração oral de $50 \mathrm{mg} / \mathrm{kg}$ de NAC durante 45 dias foi efetiva, removendo parcialmente a perda de peso dos diabéticos e tornando-se efetiva na restauração da atividade da ALA-D e conteúdo de NPSH no fígado, bem como diminuindo a carbonilação de proteína do soro em ratos diabéticos induzidos com aloxano. Contudo, futuros estudos são necessários para melhorar a utilização da NAC em terapias antioxidantes a fim de compreendermos os mecanismos de ação da NAC.

Palavras-chave: AChE, diabetes mellitus, NAC, estresse oxidativo.

\section{Abstract}

Diabetes mellitus is a complex chronic condition which is a major source of ill health all over the world. Extensive evidence supported that chronic hyperglycemia leads to a series of biochemical events resulting in the production of oxidative stress and neurological impairments. In view of this, adjuvant therapies using antioxidant compounds against this pathology have been suggested. N-acetylcysteine (NAC) is a compound with important antioxidant and neuromodulatory properties. Therefore, considering that the oxidative stress and cholinergic dysfunctions have been associated with the pathogenesis of different diabetic complications, the aim of this study was to investigate the effect of NAC on oxidative stress parameters and acetylcholinesterase (AChE) and aminolevulinate dehydratase (ALA-D) activities of normoglycemic and diabetic rats. The animals received 50 or $200 \mathrm{mg} / \mathrm{kg}$ NAC by gavage daily for 45 days. The results showed a lack of uniformity in AChE activity among the four cerebral structures. While neither dose of NAC produced significant hypoglycemic activity, $50 \mathrm{mg} / \mathrm{kg}$ NAC partially reversed the weight loss of diabetics and was effective in restoring ALA-D activity and non-protein thiol content in liver, and in diminishing serum protein carbonylation. The dose of $200 \mathrm{mg} / \mathrm{kg}$ NAC presented some negative effects per se in both the antioxidant and cholinergic systems. Therefore, we conclude that oral administration of $50 \mathrm{mg} / \mathrm{kg}$ NAC during 45 days was effective partially reversing the loss weight of diabetics and being effective in restore ALA-D activity 
and NPSH content in liver, as well as diminishing serum protein carbonylation in alloxan-induced diabetic rats. However, future studies are necessary to improve the use of NAC in antioxidant therapies in order to understand the mechanisms of NAC action.

Keywords: AChE, diabetes mellitus, NAC, oxidative stress.

\section{Introduction}

Diabetes mellitus, a group of chronic metabolic disorders affecting millions of people around the world, is characterized by hyperglycemia that affects carbohydrate, fat and protein metabolisms resulting from impairment in insulin secretion, insulin action, or both (American Diabetes Association Diagnosis and Classification of Diabetes Mellitus, 2006). This disease in humans and experimental models is associated with neurochemical, neurophysiological, and behavioral modifications as well as vascular disturbances in brain function and integrity (Biessels et al., 2002; Mazzanti et al., 2006). In this context, our research group have demonstrated that both purinergic and cholinergic neurotransmission is impaired in diabetic rats by altering ecto-nucleoside triphosphate phosphohydrolase, ecto-5'-nucleotidase and acetylcholinesterase (AChE; E.C. 3.1.1.7) activities (Schmatz et al., 2009a,b,c).

$\mathrm{AChE}$ is an important regulatory enzyme that promotes the hydrolysis of the neurotransmissor acetylcholine (ACh) in the synaptic cleft of cholinergic synapses and neuromuscular junctions (Mazzanti et al., 2006) and has an essential role in regulating many vital functions, such as learning, memory, cortical organization of movement and cerebral blood flow control (Appleyard, 1992). The cholinesterases and their activities are considered a good indicator of cholinergic activity (Mazzanti et al., 2006; Schmatz et al., 2009a,b,c).

Moreover, heme biosynthesis is impaired in a group of diseases named porphyrias, mainly porphyria cutanea tarda, in which a higher incidence of diabetes mellitus than in the general population has been observed. $\delta$-Aminolevulinate dehydratase ( $\delta$-ALA-D), an enzyme in the heme biosynthesis pathway, is essential for all aerobic organisms and catalyses the asymmetric condensation of two molecules of 5 -aminolevulinic acid ( $\delta$-ALA) to form the monopyrrole porphobilinogen (PBG) (Fernández-Cuartero et al., 1999). Moreover, it is a marker for oxidative stress because its active sulfhydryl group renders it highly sensitive to pro-oxidant elements which impair its function (Jacques-Silva et al., 2001). 
Oxidative stress has been associated with the pathogenesis of different diabetic complications (Elias et al., 2008; Ha et al., 2008; Hamdem et al., 2009). Several studies have reported that enzymatic and/or non-enzymatic antioxidant systems are impaired in diabetes (Barbosa et al., 2008; Hamdem et al., 2009). The prooxidant-antioxidant imbalance in diabetes may be due to acceleration of some cellular reactions that lead to increased radical production, such as non-enzymatic protein glycosylation, glucose oxidation and increased sorbitol pathway, or reduced antioxidant defense potential (Ha et al., 2008). Also, advanced glycation end-products (AGEs) have been hypothesized to be associated with an excess of glucose and to be formed via oxidative denaturation (Miyata \& Dan, 2008). In view of this, treatment with antioxidants, antihyperglycemics and cholinergic agonists are reported to produce beneficial effect in diabetic state. In fact, treatment with the antioxidant compound berberine prevents the changes in oxidative stress and AChE activity, and consequently memory impairment in diabetic rats (Bhutada et al. (2011). Sefi et al. (2010) demonstrated the antioxidant properties of Artemisia campestris leaf extract on hyperlipidemia, AGEs and oxidative stress in alloxan-induced diabetic rats preventing diabetic complications. Punithavathi et al. (2011) reported antihyperglycaemic, antilipid peroxidative and antioxidant effects of gallic acid on diabetic rats induced by streptozotocin. Moreover, our group and others recently demonstrated that the antioxidant resveratrol and the medicinal plant ginger have a protector effect against hepatic and renal damage induced by oxidative stress in diabetic rats (Shanmugam et al., 2011; Schmatz et al., 2012).

The induction of experimental diabetes in rats using chemicals such as alloxan and streptozotocin is very convenient and simple. Alloxan causes a massive reduction in insulin release, by the destruction of the $\beta$-cells of the Langerhans islets, inducing hyperglycemia (Szkudelski, 2001). $\mathrm{N}$-acetylcysteine (NAC) can effectively and specifically inhibit activation of the pancreatic nuclear factor NFkB and is able to attenuate the severity of the disease (Ho et al., 1999). NAC act as an antioxidant compound by directly to scavenge hydrogen peroxide $\left(\mathrm{H}_{2} \mathrm{O}_{2}\right)$, hydroxyl free radicals $(\cdot \mathrm{OH})$ and hypochloric acid ( $\mathrm{HOCl})$ in vitro, and it decreases free radical levels acting as a precursor of glutathione (GSH) to facilitate intracellular GSH synthesis (Sagristá et al., 2002). In fact, Dean et al. (2004) demonstrated that NAC crosses the blood brain barrier, replenishes brain GSH, enhances neurogenesis of neuronal stem cells and promotes neuronal survival in a rat model. 
Furthermore, NAC has potential to reverse cognitive dysfunction and oxidative stress induced by bisphenol A in rats (Jain et al., 2011). This potential antioxidant and neuroprotective effects of NAC have been demonstrated in a variety of neurodegenerative disease models (Andreassen et al., 2000; Berk et al., in press). Moreover, our group recently published that NAC prevents memory deficits, the decrease in AChE activity, the hematological impairments, and oxidative stress in rats exposed to cadmium (Gonçalves et al., 2010; Gonçalves et al. in press).

Thus, the objective of the present study was to contribute to a better understanding of the NAC effects on diabetes because of its well-known antioxidant characteristics. In order to obtain these results, normoglycemic and alloxan-induced rats were used to evaluate the effect of NAC on AChE and ALA-D activities and their relation to antioxidant system.

\section{Material and methods}

\section{Chemicals}

Acetylthiocholine iodide, 5,5'-dithio-bis-2-nitrobenzoic acid (DTNB), tris-(hydroxymethyl)-aminomethane GR, Coomassie brilliant blue G and thiobarbituric acid (TBA) were obtained from Sigma Chemical Co. (St. Louis, MO, USA). Bovine serum albumin was purchased from Reagen. N-acetylcysteine was obtained from Beg (São Paulo, SP, Brazil) with 99.1\% of purity. All other reagents used in the experiments were of analytical grade and of the highest purity.

\section{Animals}

Adult male Wistar rats $(150-230 \mathrm{~g})$ obtained from the Central Animal House of the Federal University of Santa Maria (Santa Maria, RS, Brazil) were used in this experiment. The animals were maintained at a constant temperature $\left(23 \pm 1^{\circ} \mathrm{C}\right)$ on a 12 hours light/dark cycle with free access to food and water. All animal procedures were approved by the Animal Ethics Committee from UFSM (protocol under number: 23081.003049/2006-61).

\section{Experimental induction of diabetes}

Diabetes was induced, in overnight-fasted rats, by a single intraperitoneal injection (i.p.) of alloxan monohydrate in a fresh solution of $0.05 \mathrm{M}$ sodium 
citrate (pH 4.5) at a dose of $150 \mathrm{mg} / \mathrm{kg}$ body weight. Since alloxan is capable of producing fatal hypoglycemia as a result of massive pancreatic insulin release, rats were treated with $20 \%$ glucose solution $(2 \mathrm{ml})$ orally after $6 \mathrm{~h}$ of induction with alloxan. The rats were then kept for the next $24 \mathrm{~h}$ on $5 \%$ glucose solution bottles as a substitute for water in their cages to prevent hypoglycemia.

The diabetic state was checked and confirmed 15 days after induction. Blood samples were collected from the caudal vein and glucose was measured with a portable glucometer (ADVANTAGE, Boehringer Mannheim, MO, USA). Only animals with fasting glycemia over $200 \mathrm{mg} / \mathrm{dl}$ were considered diabetic and selected for the experiment. Animals described as fasting were deprived of food but allowed free access to drinking water.

\section{Treatment}

Animals were randomly divided into six different groups ( 6 rats per group). The treatment groups can be summarized as follows: group I, control/saline; group II, control/NAC50 (50 mg NAC/kg body weight), group III, control/ NAC200 (200 mg NAC/kg body weight); group IV, diabetic/saline; group V, diabetic/NAC50 (50 mg NAC/kg body weight); group VI, diabetic/NAC200 (200 mg NAC/kg body weight). The choice of the doses of 50 and $200 \mathrm{mg} / \mathrm{kg}$ of NAC was made based in several studies that used these same doses of NAC and obtained beneficial results (Sadowska et al., 2007 and references therein). $\mathrm{N}$-acetylcysteine (NAC) was freshly prepared in saline and was administered ( $1 \mathrm{~mL} / \mathrm{kg}$ ) by gavage daily, seven times/week, for 45 days between 9 and 11 a.m.

At the onset (15 days after alloxan or saline injection) and at the end of the experiment (45 days after NAC treatment) the body weight of rats were measured. At the end of the experimental period, the rats were deprived of food overnight and then euthanized by heart puncture. After that, the liver, kidney and brain were carefully removed. The cranium was opened and the structures were gently removed and separated into cerebellum (CE) cerebral cortex (CC), striatum (ST) and hippocampus (HP).

\section{Acetylcholinesterase assay (AChE; E. C. 3.1.1.7)}

The four brain structures selected for the experiment (CE, CC, ST and $\mathrm{HP}$ ) were maintained refrigerated in a solution of $10 \mathrm{mM}$ Tris- $\mathrm{HCl}, \mathrm{pH}$ 7.4, on ice. The tissues were homogenized in a glass potter in Tris- $\mathrm{HCl}$ solution at a proportion of 1:10 (w/v) and then centrifuged at $3500 \mathrm{rpm}$ for 
10 min to yield a supernatant that was used for the enzyme assay. AChE activity was determined by a modification of the spectrophotometric method of Ellman et al. (1961). The assay medium (2 ml final volume) contained $100 \mathrm{mM}$ potassium phosphate buffer ( $\mathrm{pH}$ 7.5) and $1 \mathrm{mM}$ 5,5'-dithio-bis-2-nitrobenzoic acid (DTNB). One hundred microliters of supernatant from the brain structures were pre-incubated for $2 \mathrm{~min}$ at $25^{\circ} \mathrm{C}$. The reaction was initiated by adding $200 \mu \mathrm{l}$ of $0.8 \mathrm{mM}$ acetylthiocholine iodide (AcSCh) as the substrate. After pre-incubation, the reaction speed was measured by increasing absorbance to $412 \mathrm{~nm}$. The enzyme activity was expressed in $\mu \mathrm{mol} \mathrm{AcSCh} / \mathrm{h} / \mathrm{mg}$ protein.

\section{$\delta$ - aminolevulinic acid dehydratase assay ( $A L A-D$; \\ E.C. 4.2.1.24)}

ALA-D activity of livers and kidneys were assayed according to the method of Sassa (1982) by measuring the rate of porphobilinogen (PBG) formation, except that in all enzyme assays the final concentration of ALA was $2.2 \mathrm{mM}$. Samples were homogenized in $50 \mathrm{mM}$ Tris- $\mathrm{HCl}(\mathrm{pH} 7.5)$ at a proportion of 1:10 (w/v) and centrifuged at $3000 \mathrm{rpm}$ for $10 \mathrm{~min}$. An aliquot of $200 \mu \mathrm{l}$ of supernatant was incubated during $0.5 \mathrm{~h}$ for liver and $\mathrm{l} \mathrm{h}$ for kidney at $37^{\circ} \mathrm{C}$. The reaction was stopped by addition of $250 \mu$ of trichloroacetic acid (TCA). The reaction product was determined using modified Ehrlich's reagent at $555 \mathrm{~nm}$. ALA-D activity was expressed as nmol PBG/mg protein/h.

\section{Catalase assay (CAT; E.C. 1.11.1.6)}

For the CAT assay, rat livers and kidneys were homogenized in $50 \mathrm{mM}$ potassium phosphate buffer, $\mathrm{pH} 7.5$, at a proportion of $1: 9(\mathrm{w} / \mathrm{v})$ and $1: 5(\mathrm{w} / \mathrm{v})$, respectively. The homogenate was centrifuged at $3000 \mathrm{rpm}$ for $10 \mathrm{~min}$ to yield a supernatant that was used for the enzyme assay. CAT activity was measured by the method of Nelson and Kiesow (1972). The reaction mixture contained $50 \mathrm{mM}$ potassium phosphate buffer ( $\mathrm{pH}$ 7.5), $10 \mathrm{mM} \mathrm{H}_{2} \mathrm{O}_{2}$ and $20 \mu \mathrm{l}$ of the supernatant. The rate of $\mathrm{H}_{2} \mathrm{O}_{2}$ reaction was monitored at $240 \mathrm{~nm}$ for $2 \mathrm{~min}$ at room temperature. Enzyme activity was expressed as $\Delta \mathrm{E} / \mathrm{min} / \mathrm{mg}$ protein. 


\section{Ascorbic acid (AsA) and Non-protein thiol groups}

\section{(NPSH) contents}

For determination of AsA and NPSH contents, livers and kidneys were homogenized in $50 \mathrm{mM}$ Tris- $\mathrm{HCl}$ buffer, $\mathrm{pH} 7.5$, at a proportion of 1:10 (w/v). The homogenate was centrifuged at $3000 \mathrm{rpm}$ for $10 \mathrm{~min}$. The supernatant was precipitated in a cold 10\% TCA solution at a proportion of 1:1 (v/v) and submitted to the same centrifugation again. This supernatant was then used for analysis.

Ascorbic acid determination was performed as described by Jacques-Silva et al. (2001). An $300 \mu \mathrm{l}$ aliquot of sample in a final volume of $575 \mu \mathrm{l}$ of solution was incubated for $3 \mathrm{~h}$ at $37^{\circ} \mathrm{C}$ then $500 \mu \mathrm{H}_{2} \mathrm{SO}_{4} 65 \%$ (v/v) was added to the medium. The reaction product was determined using a color re-

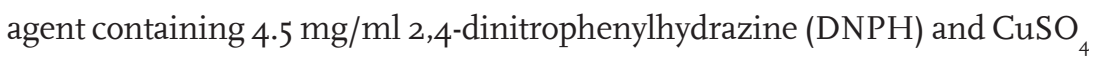
$(0.075 \mathrm{mg} / \mathrm{ml})$. AsA levels were expressed as $\mu$ g ascorbic acid/g tissue.

NPSH was measured spectrophotometrically with Ellman's reagent (1959). An aliquot of $100 \mu \mathrm{l}$ for liver and $200 \mu \mathrm{l}$ for kidney in a final volume of $900 \mu \mathrm{l}$ of solution was used for the reaction. The reaction was read at 412 $\mathrm{nm}$ after the addition of $10 \mathrm{mM}$ DTNB $(0.05 \mathrm{ml})$. A standard curve using cysteine was added to calculate the content of thiol groups in samples, and was expressed as $\mu \mathrm{mol} \mathrm{SH} / \mathrm{g}$ tissue.

\section{Carbonylation}

Reaction with DNPH is a standard method for detecting carbonyl groups that can be used to follow changes on protein oxidation. The carbonylation of serum proteins was determined by modifications of Levine et al. (1990) method. Firstly, from $1 \mathrm{ml}$ of serum, the proteins were precipitated using $0.5 \mathrm{ml}$ of $10 \%$ TCA and centrifuged at 5000 rpm for 5 min and the supernatant was discarded. One half milliliter of $10 \mathrm{mM}$ DNPH in $2 \mathrm{M} \mathrm{HCl}$ was added to this protein precipitate and incubated at room temperature for $30 \mathrm{~min}$. During the incubation time the samples were mixed vigorously every $15 \mathrm{~min}$. After the incubation time, $0.5 \mathrm{ml}$ of $10 \%$ TCA was added to the protein precipitate and centrifuged at $5000 \mathrm{rpm}$ for $5 \mathrm{~min}$. After discarding the supernatant, precipitates were washed twice with $1 \mathrm{ml}$ ethanol/ethylacetate (1:1), each time centrifuging out the supernatant in order to remove the free DNPH. The precipitate was dissolved in $1.5 \mathrm{ml}$ of protein dissolving solution (2 $\mathrm{g}$ SDS and $50 \mathrm{mg}$ EDTA in $100 \mathrm{ml} 80 \mathrm{mM}$ phosphate buffer, $\mathrm{pH} \mathrm{8.0)} \mathrm{and} \mathrm{incubated}$ 
at $37^{\circ} \mathrm{C}$ water bath for $10 \mathrm{~min}$. The color intensity of the supernatant was measured using a spectrophotometer at $370 \mathrm{~nm}$ against $2 \mathrm{M} \mathrm{HCl}$. Carbonyl content was calculated by using the molar extinction coefficient $\left(21 \mathrm{X}_{10^{3}} \mathrm{~L} /\right.$ $\mathrm{mol} \mathrm{cm}$ ) and results were expressed as nmol carbonyl/mg protein.

\section{Protein determination}

In all the enzyme preparations, protein was measured according to Bradford (1976) using bovine serum albumin as standard. For brain tissues, the protein was determined previously and adjusted for each structure: CE (0.5 mg/ml), CC (0.7mg/ml), HP (0.8 mg/ml) and ST (0.4 mg/ml).

\section{Statistical analysis}

All data were expressed as mean \pm S.E.M. of four to six observations per group and statistically assessed by two-way ANOVA for fasting glucose levels and body weight and by one-way ANOVA for other parameters followed by Duncan's multiple range test when the F test was significant $(P<0.05)$ to determine differences among the groups.

\section{Results}

\section{Blood glucose levels and rat body weights}

The effect of different doses of NAC on fasting blood glucose levels and rat body weights of both control and diabetic rats at the onset (15 days after alloxan or saline injection) and the end of the experiment (45 days after NAC treatment) is given in Table 1. In all groups prior to alloxan administration, the basal levels of blood glucose were not significantly different (data not shown). The fasting blood glucose levels of the diabetic/saline group were significantly higher than those of the control/saline group at the onset and at the end of the experiment $(P<0.05)$. The treatment with different doses of NAC in both control and diabetic rats did not produce any hypoglycemic activity $(P<0.05)$.

The control/saline group showed a $40 \%$ increase in body weight at the end of the experiment. On the other hand, the body weight of diabetic/saline and diabetic/NAC200 was significantly lower at the end of the study in comparison to control/saline group $(P<0.05)$. Treatment with $50 \mathrm{mg} / \mathrm{kg}$ of NAC decreased the diabetes-induced reduction in body weight $(P<0.05)$. 
Table 1. The effect of different doses of $\mathrm{N}$-acetylcysteine (NAC) on fasting blood glucose levels and body weight in control and diabetic rats at the onset ( 15 days after alloxan or saline injection) and the end of the experiment ( 45 days after NAC treatment).

\begin{tabular}{c|c|c|c|c}
\hline Groups & \multicolumn{2}{|c|}{ Blood glucose levels $(\mathrm{mg} / \mathrm{dL})$} & \multicolumn{2}{c}{ Rat body weight $(\mathrm{g})$} \\
\hline & Onset & End & Onset & End \\
\hline control/saline & $64.0 \pm 3 \mathrm{Ca}$ & $69.3 \pm 3 \mathrm{Ba}$ & $204.7 \pm 5 \mathrm{Ab}$ & $292.6 \pm 9 \mathrm{Aa}$ \\
\hline control/NAC50 & $61.4 \pm 2 \mathrm{Ca}$ & $70.0 \pm 3 \mathrm{Ba}$ & $202.2 \pm 9 \mathrm{Ab}$ & $283.8 \pm 12 \mathrm{Aa}$ \\
\hline control/NAC200 & $60.5 \pm 4 \mathrm{Ca}$ & $71.5 \pm 2 \mathrm{Ba}$ & $215.6 \pm 11 \mathrm{Ab}$ & $291.9 \pm 17 \mathrm{Aa}$ \\
\hline diabetic/saline & $395.5 \pm 27 \mathrm{Aa}$ & $347.0 \pm 46 \mathrm{Aa}$ & $161.5 \pm 9 \mathrm{Ba}$ & $161.5 \pm 10 \mathrm{Ca}$ \\
\hline diabetic/NAC50 & $307.1 \pm 21 \mathrm{Ba}$ & $303.8 \pm 12 \mathrm{Aa}$ & $215.4 \pm 10 \mathrm{Aa}$ & $224.0 \pm 10 \mathrm{Ba}$ \\
\hline diabetic/NAC200 & $294.3 \pm 13 \mathrm{Ba}$ & $298.7 \pm 17 \mathrm{Aa}$ & $196.9 \pm 11 \mathrm{Aa}$ & $180.3 \pm 15 \mathrm{Ca}$ \\
\hline
\end{tabular}

Values are expressed as mean \pm S.E.M. $n=4-6$ observations per group. Different capital letters indicate significant differences among the groups $(p<0.05)$. Different lower case letters indicate significant differences between the onset and the end of the experiments $(P<0.05)$.

\section{AChE activity in brain}

The results obtained for AChE activity in brain structures are presented in Figure 1. As can be observed, in CE there was no significant alteration in AChE activity among the groups $(P>0.05)$ (Figure $1 \mathrm{~A})$. In CC, AChE activity was significantly decreased in the diabetic/NAC50 and diabetic/NAC200 groups $(P<0.05)$ compared to the control/saline and diabetic/saline groups (Figure $1 B)$. On the other hand, treatment with NAC per se significantly increased ST AChE activity in the control/NAC200 group $(P<0.05)$ when compared to the control/saline group (Figure $1 \mathrm{C}$ ). Oral administration of NAC had no significant effect on HP AChE activity of controls and diabetic rats compared to the control/saline and diabetic/saline groups, but there was a significant reduction in AChE activity in this structure in the diabetic/saline group when compared to the control/saline group (Figure 1D). 

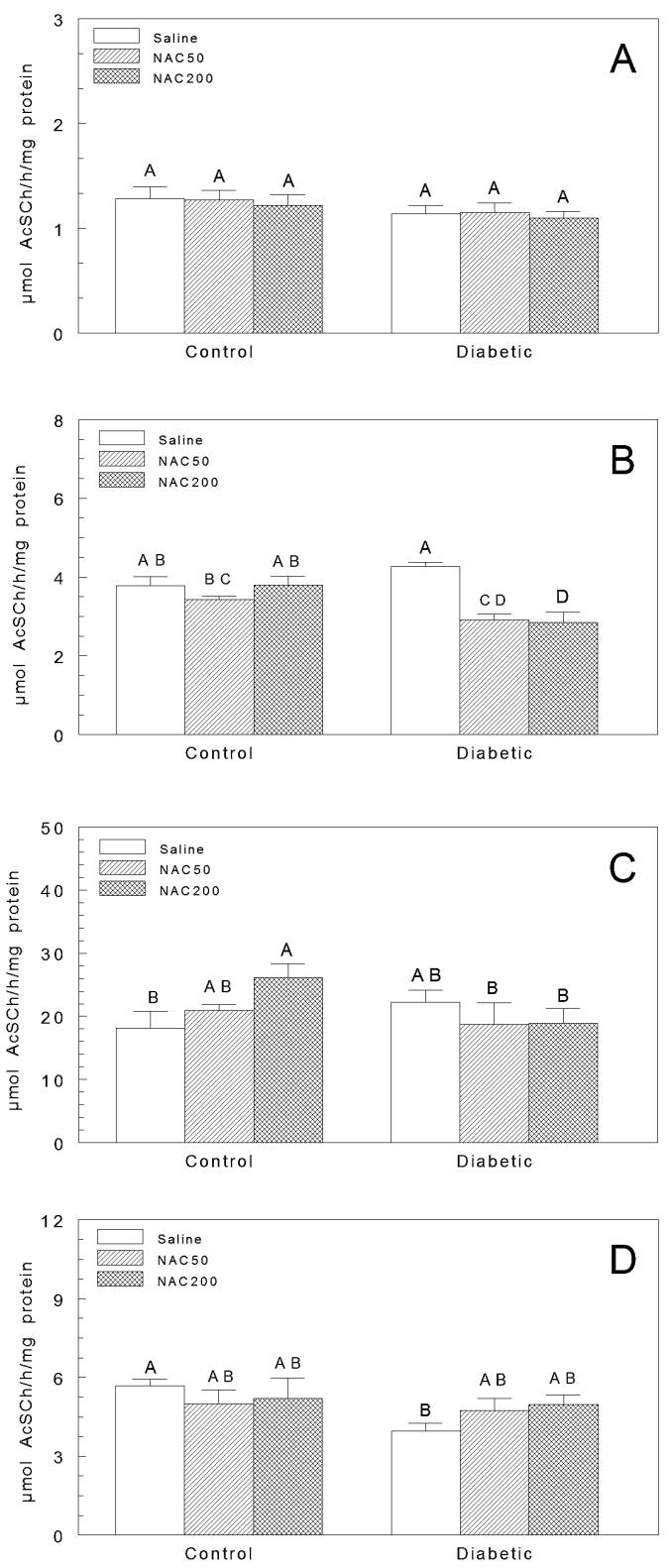

Figure 1. Effect of 45 days of oral treatment with $\mathrm{N}$-acetylcysteine (NAC) on AChE activity in the cerebellum (A), cerebral cortex (B), striatum (C) and, hippocampus (D). Values are expressed as mean \pm S.E.M. $n=4-6$ observations per group. Different capital letters indicate significant differences among the groups $(P<0.05)$. 


\section{Pro-oxidant parameters: liver and kidney ALA-D activity and serum carbonyl groups}

Figure 2 illustrates tissue ALA-D activity and serum carbonyl groups of control and experimental animals. Liver ALA-D activity showed a 35\% decrease in the diabetic/saline group $(P<0.05)$ compared to the control/saline group (Figure 2A). This reduction in hepatic ALA-D activity did not occur when NAC was administered after alloxan treatment for 45 days $(P<0.05)$. On the other hand, there were no significant differences among the control and the alloxan-induced rats in kidney ALA-D activity $(P<0.05)$ (Figure $2 \mathrm{~B})$.

There was a significant increase of $55 \%$ in the serum content of carbonyl in the diabetic/saline group $(P<0.05)$ compared to the control/saline group (Figure $2 \mathrm{C}$ ). This increase in carbonyl did not occur when $50 \mathrm{mg} / \mathrm{kg}$ of NAC was administered in diabetic rats and it was partially reversed by $200 \mathrm{mg} / \mathrm{kg}$ of NAC $(P>0.05)$.
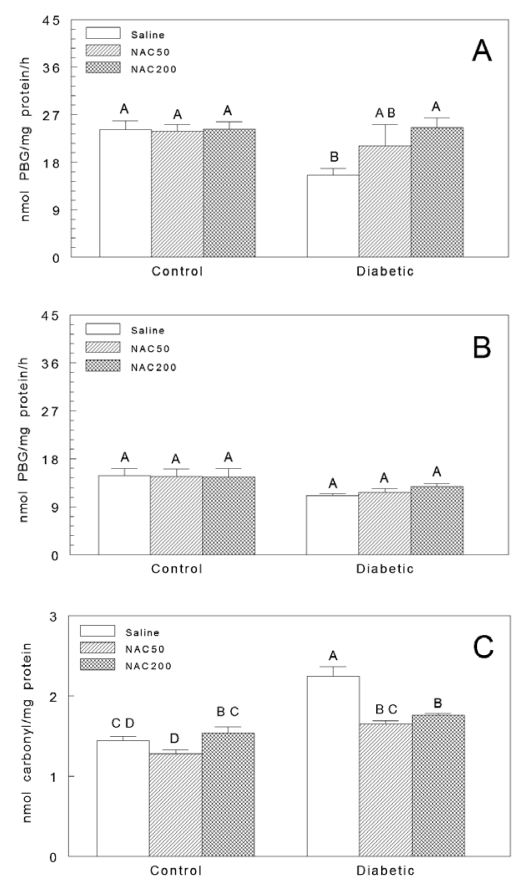

Figure 2. Effect of 45 days of oral treatment with $N$-acetylcysteine (NAC) on ALA-D activity in liver (A) and kidney (B) and on serum protein carbonylation (C). Values are expressed as mean \pm S.E.M. $n=4-6$ observations per group. Different capital letters indicate significant differences among the groups $(P<0.05)$. 


\section{Antioxidant parameters: CAT activity and AsA and NPSH content in kidney and liver tissues}

CAT activity and AsA and NPSH contents in kidney and liver tissues are shown in Figure 3. Liver CAT activity was significantly decreased in the diabetic/saline, diabetic/NAC50 and diabetic/NAC200 groups $(P<0.05)$ compared to the control/saline group (Figure 3A). Kidney CAT activity decreased only in the diabetic/NAC200 group $(P<0.05)$ compared to the control/saline group (Figure $3 \mathrm{~B}$ ). Administration of NAC caused a decrease in CAT activity in both liver and kidney of alloxan-induced rats $(P<0.05)$ compared to their respective control/NAC groups.

There was a significant reduction in both liver and kidney AsA content in the diabetic/saline, diabetic/NAC50 and diabetic/NAC200 groups $(P<0.05)$ compared to the control/saline group (Figures $3 \mathrm{C}$ and D). Oral treatment with NAC per se significantly decreased liver AsA content in the control/ NAC200 group $(P<0.05)$ when compared to the control/saline group. Administration of NAC caused a decrease in AsA content in both tissues of alloxan-induced rats $(P<0.05)$ compared to their respective control/NAC groups.

Liver NPSH content was significantly decreased in the diabetic/saline, diabetic/NAC50 and diabetic/NAC200 groups $(P<0.05)$ compared to the control/saline group (Figure $3 \mathrm{E}$ ). Oral treatment with NAC per se significantly decreased liver NPSH content in the control/NAC200 group $P<0.05)$ when compared to the control/saline group. Kidney NPSH content was significantly increased in the diabetic/saline, diabetic/NAC5O and diabetic/NAC200 groups $(P<0.05)$ compared to the control/saline group (Figure $3 \mathrm{~F}$ ). While NAC administration had no significant effect on kidney NPSH content of diabetic rats, there was a significant increase in liver NPSH content in the diabetic/NAC50 and diabetic/NAC200 groups $(P<$ ○.05) compared to the diabetic/saline group. 

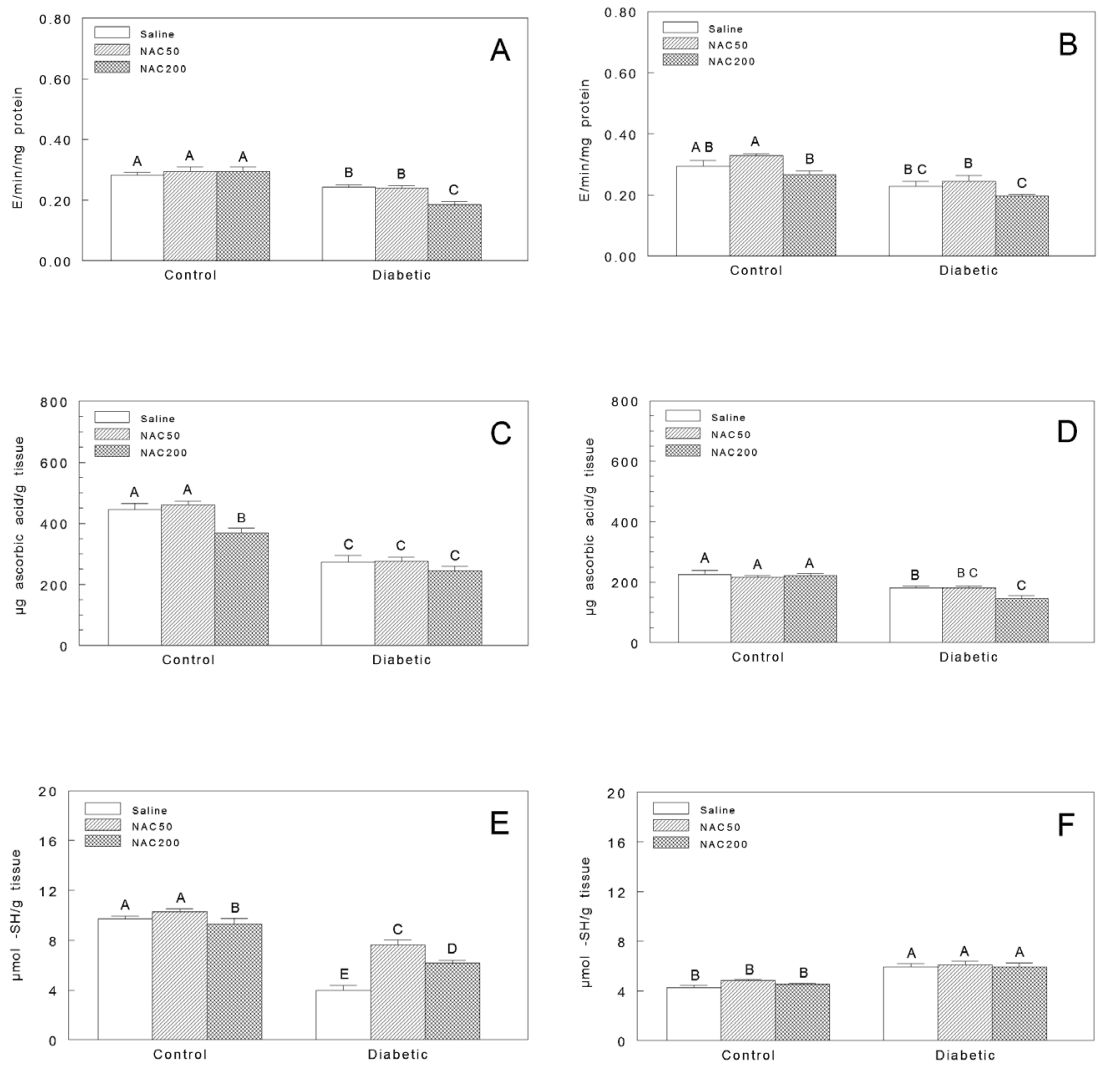

Figure 3. Effect of 45 days of oral treatment with $\mathrm{N}$-acetylcysteine (NAC) on CAT activity and AsA and NPSH content in liver ( $A, C$ and $E$, respectively) and kidney ( $B, D$ and $F$, respectively). Values are expressed as mean \pm S.E.M. $n=4-6$ observations per group. Different capital letters indicate significant differences among the groups $(P<0.05)$.

\section{Discussion}

This experimental study of alloxan-induced diabetes mellitus revealed that NAC did not produce significant hypoglycemic activity which is in accordance with Grover et al. (2000) since they postulated that the decrease in glucose levels differs in models of varying intensity of hyperglycemia. The antihyperglycemic effect of the drug is dependent upon the dose of the diabetogenic agent and therefore on the degree of $\beta$-cell destruction (Grover et al., 2000). We believe that NAC was ineffective to diminish blood glucose levels because of the severity of the diabetic model used in the present study (blood glucose 
levels higher than $300 \mathrm{mg} / \mathrm{dl}$ ) (Grover et al., 2000). Blood glucose levels in the body remain high when $\beta$-cells of the pancreas completely stop synthesizing insulin, do not make enough insulin, or when the insulin that is made does not work correctly and, depending on the severity of the diabetes, the body can not function normally (Jain et al., 2002).

Moreover, we have also observed that there was a gradual increase in body weight in the control groups while the diabetic groups did not show any significant effect on body weight throughout the treatment. Similar to previous studies (Prince et al., 1998; Schmatz et al., 2009a,b,c), in the present study the body weight of the diabetic/saline group was lower at the end of the experiment when compared to the control/saline group as a result of innumerous disturbances in the diabetic metabolism. Interestingly, when $50 \mathrm{mg} / \mathrm{kg}$ of NAC was administered to animals given alloxan, weight loss was partially reversed if compared to the diabetic/saline group, whereas at $200 \mathrm{mg} / \mathrm{kg}$ this reverse of weight loss was not observed.

Our current study showed a lack of uniformity in the profile of AChE activity among the four cerebral structures. This fact may be related with the different cholinergic projections in the brain structures. For example, the cerebral cortex and hippocampus receive cholinergic projections from the nucleus basalis of Meynert, while the striatum has an intrinsic cholinergic circuit (Kaizer et al., 2005; Mazzanti et al., 2006). This may reflect heterogeneity in the central cholinergic system (Mazzanti et al., 2006) and could indicate the importance of the cholinergic via in these different brain regions (Kaizer et al., 2005). AChE activity in cerebellum did not present any significant alteration among the groups while in cortex it was decreased in all the diabetic groups at both doses of NAC. On the other hand, in striatum $200 \mathrm{mg} / \mathrm{kg}$ of NAC per se significantly increased AChE activity when compared with the control/saline rats. Finally, while hippocampus AChE activity was decreased in the diabetic/saline group, both doses of NAC brought $\mathrm{AChE}$ levels near to those observed in the control/saline rats. Interestingly, the hippocampus plays a crucial role in synaptic plasticity (learning and memory) and in adult type 1 diabetic patients, modest reductions in mental efficiency have been reported repeatedly (Biessels et al., 2002). In fact, our group recently showed that resveratrol prevents memory deficits and the increase in AChE activity in streptozotocin-induced diabetic rats (Schmatz et al., 2009a,b). Also, Bhutada et al. (2011) demonstrated that isoquinoline alkaloid berberine might ameliorate the pathologies of diabetes-induced 
cognitive dysfunction through inhibiting the AChE activity increased in the cortex and hippocampus of diabetic rats. AChE inhibition leads to an accumulation of ACh, causing overstimulation of the receptors while AChE activation leads to a fast ACh degradation and a subsequent downstimulation of ACh receptors (Mazzanti et al., 2006). These two mechanisms can promote adverse effects. However, the finding of new drugs that per se inhibit AChE activity is useful against Alzheimer complications and compounds that are able to activate this enzyme are a scientific tool to counteract organophosphate poisoning (Benzi \& Morreti, 1998). According to Dash et al. (1991) the decreased activity of AChE observed in diabetic rats may be due to an early impairment of glucose oxidation and glucose transport, which causes specific alterations in neurotransmitter levels, thereby affecting blood brain barrier transport and causing brain dysfunction.

While in the present study there were no significant differences observed in kidney ALA-D activity, liver ALA-D activity was decreased in diabetic/saline rats when compared to control/saline rats. It is interesting to note that treatment of diabetic rats with both doses of NAC interfered with alloxan action by preventing the inhibition of hepatic ALA-D activity. The differences between kidney and liver ALA-D responses may be explained by the fact that the liver takes up more glucose than the kidney (Sidossis et al., 1999) and, consequently, the high cytosolic steady-state level of glucose in hepatocytes may favor the glycation of enzymes (ALA-D) and the production of additional free radicals associated with this type of reaction. Our tentative assumptions are supported by literature data showing that the glycation of proteins may occur intracellularly (Sidossis et al., 1999). Thus, the inhibition of ALA-D activity in liver of diabetic rats is supposed to be a consequence of glycation in the lysine residue from the active site of ALA-D, which is involved in the formation of the Schiff basis with the first molecule of ALA (Barbosa et al., 2008). Moreover, it has been reported that ALA-D inhibition can be due to the oxidation of sulfhydryl groups located at its active center. In fact, similar to our results, Pivetta et al. (2006) demonstrated a positive correlation between inhibited ALA-D activity and decreased NPSH levels in liver of rats exposed to ethanol.

In addition, ALA-D inhibition may lead to an accumulation of ALA that can cause an overproduction of reactive oxygen species (ROS) (Jacques-Silva et al., 2001) which, in turn, could exacerbate the oxidative stress caused by hyperglycemia. It has been suggested that diabetes mellitus is associated 
with weakened cellular scavenging activity, which may increase vulnerability to oxidative damage and the development of diabetic complications (Barbosa et al., 2008; Elias et al., 2008; Ha et al., 2008; Hamdem et al., 2009).

This study showed a significant increase in the carbonylation of serum proteins in the diabetic groups compared to the control groups, indicating impairment of the protein structure (Jain et al., 2002; Levine, 2002). These groups are formed by oxidation of the side chains of lysine, proline, arginine, and threonine residues (Levine, 2002). From the results obtained, it is clear that the oral administration of NAC produced a statistically significant decrease in serum protein carbonylation in diabetic rats. Corroborating with our results Jain et al. (2002) reported that NAC can inhibit high glucose-induced oxidative damage to proteins in both lens cell cultures and isolated protein solution studies.

It is well-known that glucose by itself as well as hyperglycemia-related increased protein glycosylation are important sources of ROS as elevated glucose causes slow but significant non-enzymatic glycosylation of proteins in diabetes (Miyata \& Dan, 2008). Since the glycosylation of protein is an oxidative reaction, antioxidants should be able to prevent this reaction. We therefore verified catalase activity and AsA and NPSH contents in control and diabetic rats treated with NAC, a potent ROS scavenger and thiol group supplier.

In the present study, liver CAT activity was decreased in the diabetic/ saline group when compared to control/saline rats while no significant change was shown in kidney CAT activity in the diabetic/saline group. Oral administration of NAC at 50 or $200 \mathrm{mg} / \mathrm{kg}$ caused no amelioration in the diabetic status in either tissue. A decrease in liver CAT activity in the diabetic state may be due to inactivation caused by ROS and/or by a depletion of antioxidant enzymes in response to oxidative stress (Prince et al., 1998). This corroborates with Hamdem et al. (2009) and Prince et al. (1998) who reported inhibition in hepatic CAT activity in diabetics. However, there are controversial results in the literature concerning CAT activity. In diabetics, renal and hepatic CAT activities have been reported to decrease, increase or remain unaltered (Prince et al., 1998).

Results of the current study showed that in both kidney and liver tissues, AsA content was decreased in the diabetic/saline group compared to the control/saline group. Oral administration of NAC at 50 or $200 \mathrm{mg} / \mathrm{kg}$ caused no amelioration in the diabetic status in either tissue. In liver, NAC per se at $200 \mathrm{mg} / \mathrm{kg}$ significantly decreased AsA content when compared 
to control/saline rats. Fay et al. (1990) reported that hyperglycemia and/ or hypoinsulinemia inhibit ascorbic acid cellular transport resulting in lower levels of this compound because as the chemical structure of ascorbic acid is similar to that of glucose, it shares the membrane transport system with glucose and hence competes with it for its transport. The decrease in AsA content may also be due to oxidation of AsA to dehydroascorbic acid (DHAA) or to the impaired regeneration of AsA from DHAA (Will \& Byers, 1996). According to Nonaka et al. (1991) because free radicals are normally neutralized by efficient systems in the body, including small antioxidant molecules such as AsA, increased requirements to neutralize free radicals may cause AsA concentrations to fall below normal in diabetic subjects. Moreover, it has been suggested that people with diabetes mellitus are exposed to more oxidative stress because they have lower ascorbic acid concentrations than people without this disease (Sardesai, 1995).

In our present study, the NPSH content of diabetic groups was decreased in liver and increased in kidney when compared to control/saline rats. As reported above, the liver takes up more glucose than the kidney and it may contribute to major liver damage. Glutathione (GSH), the main cellular thiol compound, has a variety of functions in bioreduction and detoxification processes. Our results suggest that increased GSH levels in the kidney of diabetic rats may function as an antioxidant defense as has been observed by our research group in patients after an ischemic event or at the beginning of tumor development (Maldonado et al., 2006; Corrêa et al., 2008). GSH, when not completely used as substrate by glutathione peroxidase in the GSH cycle, may increase inside the cells. The higher kidney GSH levels in diabetic rats when compared to the controls may be a result of the depressed enzymatic activity of glutathione peroxidase or possibly because of a relative deficiency in the glutathione peroxidase cofactor selenium (Campolo et al., 2007). Moreover, in liver, NAC per se at $200 \mathrm{mg} /$ $\mathrm{kg}$ caused a decrease in hepatic NPSH content in relation to the controls. It is interesting to note that both doses of NAC restored NPSH content in liver to near normal levels and these findings are similar to data presented by Fernández-Cuartero et al. (1999) who reported that GSH prevents the oxidation of ALA-D and concluded that a decrease of GSH levels would also explain the diminished activity of ALA-D in diabetic patients.

Taken together, the results of this study showed that NAC did not produce significant hypoglycemic activity and that $50 \mathrm{mg} / \mathrm{kg}$ NAC partially 
reversed the loss weight of diabetics and was effective in restoring ALA-D activity and NPSH content in liver, as well as in diminishing serum protein carbonylation. However, at the dose of $200 \mathrm{mg} / \mathrm{kg}$, some negative per se effects were observed in both antioxidant and cholinergic systems. In fact, Cotgreave (1997) reported that NAC in vivo failed to provide significant antioxidant effects, presumably due to its low lipid solubility and tissue distribution. In accordance, Sagristá et al. (2002) proposed a mechanism for the dual antioxidant and prooxidant behavior of NAC and GSH in an in vitro situation, suggesting that the iron-mediated oxidative metabolism of thiols may account for their prooxidant action. Ritter et al. $(2004 \mathrm{a}, \mathrm{b})$ indicated that the addition of deferoxamine (DFX) could increase the therapeutic effects of NAC for sepsis and for a severe hepatic failure model probably because of the decrease of NAC oxidation and Fenton chemistry.

\section{Conclusions}

In view of this, we conclude that oral administration of $50 \mathrm{mg} / \mathrm{kg} \mathrm{NAC}$ during 45 days was effective partially reversing the loss weight of diabetics and being effective in restore ALA-D activity and NPSH content in liver, as well as diminishing serum protein carbonylation in alloxan-induced diabetic rats. However, future studies are necessary to better use of NAC in antioxidant therapies in order to understand the mechanisms of NAC action.

\section{Acknowledgements}

The authors thank the Coordenação e Aperfeiçoamento de Pessoal de Nível Superior (CAPES), Conselho Nacional de Desenvolvimento Científico e Tecnológico (CNPq), and Fundação de Amparo à Pesquisa do Estado do Rio Grande do Sul (FAPERGS) for the research fellowships. The authors declare that there is no conflict of interest in this study.

\section{References}

ANDREASSEN, O.A.; DEDEOGLU, A.; KLIVENYI, P.; BEAL. M.F.; BUSH, A.I. N-acetyl-Lcysteine improves survival and preserves motor performance in an animal model of familial amyotrophic lateral sclerosis. Neuroreport, v. 11, p. 24912493, 2000. 
American Diabetes Association Diagnosis and Classification of Diabetes Mellitus. Diabetes Care, v. 29, p. s43-s48, 2006.

APPLEYARD, M.E. Secreted acetylcholinesterase: non-classical aspects of a classical enzyme. Trends in Neurosciences, v. 15, p. 485-490, 1992.

BARBOSA, N.B.V.; ROCHA, J.B.T.; SOARES, J.C.M.; WONDRACEK, D.C.; GONÇALVES, J.F.; SCHETINGER, M.R.C.; NOGUEIRA, C.W. Dietary diphenyl diselenide reduces the STZ-induced toxicity. Food and Chemical Toxicology, v. 46, p. 186-194, 2008.

BENZI, G.; MORRETI, A. Is there a rationale for the use of acetylcholinesterase inhibitors in the therapy of Alzheimer's disease? European Journal of Pharmacology, v. 346, p. 1-13, 1998.

BERK, M.; DEAN, O.; COTTON, S.M.; GAMA, C.S.; KAPCZINSKI, F.; FERNANDES, B.S.; KOHLMANN, K.; JEAVONS, S.; HEWITT, K., ALLWANG, C.; COBB, H.; BUSH, A.I.;, SCHAPKAITZ, I.; DODD, S.; MALHI, G.S. The efficacy of N-acetylcysteine as an adjunctive treatment in bipolar depression: an open label trial. Journal of Affective Disorders, in press.

BIESSELS, G.J.; VAN DER HEIDE, L.P.; KAMAL, A.; BLEYS, R.L.A.W.; GISPEN, W.H. Ageing and diabetes: implications for brain function. European Journal of Pharmacology, v. 441, p. 1-14, 2002.

BRADFORD, M.M. A rapid and sensitive method for quantification of microgram quantities of protein utilizing the principle of protein-dye binding. Analytical Biochemistry, v. 72, p. 248-254, 1976.

BHUTADA, P.; MUNDHADA, Y.; BANSOD, K.; TAWARI, S.; PATIL, S.; DIXIT, P.; UMATHE, S.; MUNDHADA, D. Protection of cholinergic and antioxidant system contributes to the effect of berberine ameliorating memory dysfunction in rat model of streptozotocin-induced diabetes. Behavioural Brain Research, v. 220, p. 30-41, 2011.

CAMPOLO, J.; DE MARIA, R.; CARUSO, R.; ACCINNI, R.; TURAZZA, F.; PAROLINI, M.; ROUBINA, E.; DE CHIARA, B.; CIGHETTI, G.; FRIGERIO, M.; VITALI, E.; PARODI, O. Blood glutathione as independent marker of lipid peroxidation in heart failure. International Journal of Cardiology, v. 117, p. 45-50, 2007.

CORREAA, M.C.; MALDONADO, P.; ROSA, C.S.; LUNKES, G.; LUNKES, D.S.; KAIZER, R.R.; AHMED, M.; MORSCH, V.M.; PEREIRA, M.E.; SCHETINGER, M.R.C. Oxidative stresS and erythrocyte acetylcholinesterase (AChE) in hypertensive and ischemic patients of both acute and chronic stages. Biomedicine \& Pharmacotherapy, v. 62 , p. $317-324,2008$. 
COTGREAVE, I.A. $N$-acetylcysteine: pharmacological considerations and experimental and clinical applications. Advances in Pharmacology, v. 38, p. 205-227, 1997. DASH, N.K.; AZAM, M.; GUPTA, G.; BAQUER, N.Z. Effect of hyperglycemia on acetylcholinesterase and catecholamine levels in rat brain and heart. Biochemistry International, v. 23, p. 261-269, 1991.

DEAN, O.; VAN DEN BUUSE, M.; COPOLOV, D.L.; BERK, M.; BUSH, A.I.; N-acetylcysteine treatment inhibts depletion of brain glutathione levels in rats: implications for schizophrenia, International Journal of Neuropsychopharmacology, v. 7, p. S262, 2004.

ELIAS, J.A.Z.; DELFINO, V.D.A.; BARBOSA, D.S.; FABRIS, B.A.; MATSUO, T. Efeito do ramipril e da sinvastatina sobre o estresse oxidativo de ratos diabéticos. Arquivos Brasileiros de Endocrinologia e Metabologia, v. 52, p. 1131-1138, 2008. ELLMAN, G.L. Tissue sulphydryl groups. Archives of Biochemistry and Biophysics, v. 82, p. 70-77, 1959.

ELLMAN, G.L.; COURTNEY, D.; ANDRES, V.; FEATHERSTONE, R.M. A new and rapid colorimetric determination of acetylcholinesterase activity. Biochemical Pharmacology, v. 7, p. 88-90, 1961.

FAY, M.J.; BUSH, M.J.; VERLANGIERI, A.J. Effect of cytochalasin B on the uptake of ascorbic acid and glucose by $3 \mathrm{~T}_{3}$ fibroblasts: Mechanism of impaired ascorbate transport in diabetes. Life Sciences, v. 46, p. 619-624, 1990. FERNÁNDEZ-CUARTERO, B.; REBOLLAR, J.L.; BATLLE, A.; ENRIQUEZ DE SALAMANCA, R. Delta aminolevulinate dehydratase (ALA-D) activity in human and experimental diabetes mellitus. International Journal of Biochemistry \& Cell Biology, v. 31, p. 479-488, 1999.

GONÇALVES, J.F., DUARTE, M.M.M.F., FIORENZA, A.M., SPANEVELLO, R.M., MAZZANTI, C.M., SCHMATZ, R., BAGATINI, M.D., ANTES, F.G., COSTA, P, ABDALLA, F.H., DRESSLER, V.L., MORSCH, V.M., SCHETINGER, M.R.C. Hematological indices and activity of NTPDase and cholinesterase enzymes in rats exposed to cadmium and treated with $\mathrm{N}$-acetylcysteine. Biometals, in press.

GONÇALVES, J.F.; FIORENZA, A.M.; SPANEVELLO, R.M.; MAZZANTI, C.M.; BOCHI, G.V.; ANTES, F.G.; STEFANELLO, N.; RUBIN, M.A.; DRESSLER, V.L.; MORSCH, V.M.; SCHETINGER, M.R.C. N-acetylcysteine prevents memory deficits, the decrease in acetylcholinesterase activity and oxidative stress in rats exposed to cadmium. Chemico-Biological Interactions, v. 186, p. 53-60, 2010. 
GROVER, J.K.; VATS, V.; RATHI, S.S. Anti-hyperglicemic effect of Eugenia jambolana and Thospora cordifolia in experimental diabetes and their key metabolic enzymes involved in carbohydrate metabolism. Journal of Ethnopharmacology, v. 73, p. 461-470, 2000.

HA, H.; HWANG, IN-A.; PARK, J.H.; LEE, H.B. Role of reactive oxygen species in the pathogenesis of diabetic nephropathy. Diabetes Research and Clinical Practice, v. 82, p. s42-s45, 2008.

HAMDEM, K.; BOUJBIHA, M.A.; MASMOUDI, H.; AYADI, F.M.; JAMOUSSI, K.; ELFEKI, A. Combined vitamins ( $\mathrm{C}$ and $\mathrm{E}$ ) and insulin improve oxidative stress and pancreatic and hepatic injury in alloxan diabetic rats. Biomedicine \& Pharmacotherapy, v. 63, p. 95-99, 2009.

HO, E.; CHEN, G.; BRAY, T.M. Supplementation of $N$-acetylcysteine inhibits NFkappaB activation and protects against alloxan-induced diabetes in CD- mice. Journal of the Federation of American Societies for Experimental Biology, v. 13, p. 1845-1854, 1999.

JACQUES-SILVA, M.C.; NOGUEIRA, C.W.; BROCH, L.C.; FLORES, E.M.M.; ROCHA, J.B.T. Diphenyl diselenide and ascorbic acid changes deposition of selenium and ascorbic acid in liver and brain of mice. Pharmacology \& Toxicology, v. 88, p. 119-125, 2001.

JAIN, A.K.; LIM, G.; LANGFORD, M.; JAIN, S.K. Effect of high-glucose levels on protein oxidation in cultured lens cells, and in crystalline and albumin solution and its inhibition by vitamin $\mathrm{B}_{6}$ and $\mathrm{N}$-acetylcysteine: Its possible relevance to cataract formation in diabetes. Free Radical Biology \& Medicine, v. 33, p. 1615-1621, 2002.

KAIZER, R.R.; CORRÊA, M.C.; SPANEVELLO, R.M.; MORSCH, V.M.; MAZZANTI, C.M.; GONÇALVES, J.F.; SCHETINGER, M.R.C. Acetylcholinesterase activation and enhanced lipid peroxidation after long-term exposure to low levels of aluminum on different mouse brain regions. Journal of Inorganic Biochemistry, v. 99, p. 1865-1870, 2005. LEVINE, R.L. Carbonyl modified proteins in cellular regulation, aging, and disease. Free Radical Biology \& Medicine, v. 32, p. 790-796, 2002.

LEVINE, R.L.; GARLAND, D.; OLIVER, C.N.; AMICI, A.; CLIMENT, I.; LENZ, A. Determination of carbonyl content in oxidatively modified proteins. Methods in Enzymology, v. 186, p. 464-478, 1990. 
MALDONADO, P.A.; NEGRINI, L.A.; KAIZER, R.R.; ZANIN, R.F.; ARAÚJO, M.C.; BATTISTI, V.; MORSCH, V.M.; SCHETINGER, M.R.C. Oxidative status in patients submitted to conization and radiation treatments for uterine cervix neoplasia. Clinica Chimica Acta, v. 366, p. 174-178, 2006.

MAZZANTI, C.M.; SPANEVELLO, R.M.; PEREIRA, L.B.; GONÇALVES, J.F.; KAIZER, R.R.; CORRÊA, M.; AHMED, M.; MAZZANTI, A.; FESTUGATTO, R.; GRAÇA, D.L.; MORSCH, V.M.; SCHETINGER, M.R.C. Acetylcholinesterase Activity in Rats Experimentally Demyelinated with Ethidium Bromide and Treated with Interferon Beta. Neurochemical Research, v. 31, p. 1027-1034, 2006.

MIYATA, T.; DAN, T. Inhibition of advanced glycation end products (AGEs): An implicit goal in clinical medicine for the treatment of diabetic nephropathy? Diabetes Research and Clinical Practice, v. 82, p. s25-S29, 2008.

NELSON, D.P.; KIESOW, L.A. Entalpy of the composition of hydrogen peroxide by catalase at $25^{\circ} \mathrm{C}$. Analytical Biochemistry, v. 49, p. 474-479, 1972.

NONAKA, A.; MANABE, T.; TOBE, T. Effect of a new synthetic ascorbic acid derivative as a free radical scavenger on the development of acute pancreatitis in mice. Gut, v. 32, p. 528-532, 1991.

PIVETTA, L.A.; PEREIRA, R.P.; FARINON, M.; BEM, A.F.; PEROTTONI, J.; SOARES, J.C.; DUARTE, M.M.F.; ZENI, G.; ROCHA, J.B.T.; FARINA, M. Environmental Toxicology and Pharmacology, v. 21, p. 338-343, 2006.

PRINCE, P.S.M.; MENON, V.P.; PARI, L. Hypoglycaemic ativity of Syzygium cumini seeds: effect on lipid peroxidation in alloxan diabetic rats. Journal of Ethnopharmacology, v. 61, p. 1-7, 1998.

PUNITHAVATHI, V.H.; PRINCE, P.S.M.; KUMAR, R.; SELVAKUMARI, J. Antihyperglycaemic, antilipid peroxidative and antioxidant effects os garlic on streptozotocin- induced diabetic rats. European Journal of Pharmacology, v. 650, p. 465-471, 2011.

RITTER, C.; ANDRADES, M.E.; REINKE, A.; MENNA-BARRETO, S.; MOREIRA, J.C.; DAL-PIZZOL, F. Treatment with N-acetylcysteine plus deferoxamine protects rats against oxidative stress and improves survival in sepsis. Critical Care Medicine, v. 32, p. 342-349, 2004 a.

RITTER, C.; REINKE, A.; ANDRADES, M.; MARTINS, M.R.; ROCHA, J.; MENNA-BARRETO, S.; QUEVEDO, J.; MOREIRA, J.C.; DAL-PIZZOL, F. Protective effect of N-acetylcysteine and deferoxamine on carbon tetrachloride-induced acute hepatic failure in rats. Critical Care Medicine, v. 32, p. 2079-2083, 2004b. 
SADOWSKA, A.M.; MANUEL-Y-KEENOY, B.; DE BACKeR, W.A. Antioxidant and anti-inflamatory efficacy of NAC in the treatment of COPD: Discordant in vitro and in vivo dose-effects: A review. Pulmonary Pharmacology and Therapeutics, v. 20, p. 9-22, 2007.

SAGRISTÁ, M.L.; GARCÍA, A.F.; MADARIAGA, M.A.; MORA, M. Antioxidant and Prooxidant: Effect of the thiolic compounds $\mathrm{N}$-acetyl-L-cysteine and glutathione against free radical-induced lipid peroxidation. Free Radical Research, v. 36, p. 329-340, 2002 .

SARDESAI, V.M. Role of antioxidants in health maintenance. Nutrition in Clinical Practice, v. 10, p. 19-25, 1995.

SASSA, s. $\delta$-Aminolevulinic acid dehydratase assay. Enzyme, v. 28, p. 133$145,1982$.

SCHMATZ, R.; MAZZANTI, C.M.; SPANEVELLO, R.M.; STEFANELLO, N.; GUTIERRES, J.; CORREAA, M.; DA ROSA, M.M.; RUBIN, M.A.; SCHETINGER, M.R.C; MORSCH, V.M. Resveratrol prevents memory deficits and the increase in acetylcholinesterase activity in streptozotocin-induced diabetic rats. European Journal of Pharmacology, v. 610, p. 42-48, 2009a.

SCHMATZ, R.; MAZZANTI, C.M.; SPANEVELLO, R.M.; STEFANELLO, N.; GUTIERRES, J.; MALDONADO, P.A.; CORREAA, M.C.; DA ROSA, C.S.; BECKER, L.; BAGATINI, M.; GONÇALVES, J.F.; JAQUES, J.S.; SCHETINGER, M.R.C.; MORSCH, V.M. Ectonucleotidase and acetylcholinesterase activities in synaptosomes from the cerebral cortex of streptozotocin-induced diabetic rats and treated with resveratrol. Brain Research Bulletin, v. 80, p. 371-376, 2009b.

SCHMATZ, R.; SCHETINGER, M.R.C.; SPANEVELLO, R.M.; MAZZANTI, C.M.; STEFANELLO, N.; MALDONADO, P.A.; GUTIERRES, J.; CORREAA, M.C.; GIROTTO, E.; MORETTO, M.B.; MORSCH, V.M. Effects of resveratrol on nucleotide degrading enzymes in streptozotocin-induced diabetic rats. Life Sciences, v. 84, p. 345-350, 2009 c.

SCHMATZ, R.; PEREIRA, L.B.; STEFANELLO, N.; MAZZANTI, C.; SPANEVELLO, R.; GUTIERRES, J.; BAGATINI, M.; MARTINS, C.C.; ABDALLA, F.H.; SERRES, J.D.S.; ZANINI, D., VIEIRA, J.M.; CARDOSO, A.M.; SCHETINGER, M.R.; MORSCH, V.M. Effects of resveratrol on biomarkers of oxidative stress and on the activity of delta aminolevulinic acid dehydratase in liver and kidney of streptozotocin-induced diabetic rats. Biochimie, v. 94, p. 374-383, 2012." 
SEFI, M.; FetOUI, H.; MAKNI, M.; ZeGHAL, N. Mitigating effects of antioxidant properties of Artemisia campestris leaf extract on hyperlipidemia, advanced glycation end products and oxidative stress in alloxan-induced diabetic rats. Food and Chemical Toxicology, v. 48, p. 1986-1993, 2010. SHANMUGAM, K.R.; MALLIKARJUNA, K.; NISHANTH, K.; KUO, C.H.; REDDY, K.S. Protective effect of dietary ginger on antioxidant enzymes and oxidative damage in experimental diabetic rat tissues. Food Chemistry, v. 124, p. 1436-1442, 2011.

SIDOSSIS, L.S.; MITTENDORFER, B.; WALSER, E.; WOLFE, R.R. Regional disposal of intravenously infused glucose during prolonged hyperglycemia-hyperinsulinemia. Journal of Nutritional Biochemistry, v. 10, p. 547-554, 1999. SZKUDELSKI, T. The mechanism of alloxan and streptozotocin action in B cells of the rat pancreas. Physiological Research, v. 50, p. 536-546, 2001. WILL, J.C.; BYERS, T. Does diabetes mellitus increase the requirement for vitamin C? Nutrition Reviews, v. 54, p. 193-202, 1996.

Submetido em: 09/11/2010

Aceito em: 06/12/2011 